\title{
The High Water Plants Water Road in Cleaning
}

\author{
Ch. H. Kuchkarova ${ }^{1^{*}}$, U. S. Nizamova ${ }^{1}$, Sh Abdullaev ${ }^{1}$ and G. A. Madrakhimova ${ }^{1}$ \\ ${ }^{1}$ Andijan Institute of Machine Building, Republic of Uzbekistan.
}

Authors' contributions

This work was carried out in collaboration among all authors. All authors read and approved the final manuscript.

Article Information

DOI: $10.9734 / A R R B / 2019 / v 33 i 530131$

Editor(s):

(1) Paola Angelini, Department of Applied Biology, University of Perugia, Perugia, Italy.

Reviewers:

(1) Junir Antonio Lutinski, Universidade Comunitária da Região de Chapecó, Brazil.

(2) R Praveen Sam, G. Pulla Reddy Engineering College, India.

Complete Peer review History: https://sdiarticle4.com/review-history/52487

Original Research Article

Received 12 August 2019

Accepted 23 October 2019

Published 08 November 2019

\section{ABSTRACT}

The ecology of high-water plants such as pistachio, euchronia, azolla forms the basis for improving biological wastewater treatment technology. For the first time in the Andizhan region of the Republic of Uzbekistan, it was found that high-altitude algae can be used by the method of biological treatment of municipal wastewater. the results of the study, we used biological treatment of high-water plant species such as pistia (Pistia stratiotes), Euchornia crassipes Solms, azolla (Azolla coroliniana Willd), with the observations of the dynamics of rapid growth and development at high concentrations. We developed a Pistia stratiotes, which is scientifically grounded in improvement, and was recommended for reproduction under laboratory conditions.

Keywords: Aquatic plants; wastewater; pistachios; euchronia; azolla; pollution; utilities; domestic; biological.

\section{INTRODUCTION}

Relevance of the topic: The current lack of sewage treatment facilities in the public utilities and manufacturing industries, and their close proximity to canals, collectors, river banks and other water bodies, results in significant contamination of water resources. The role of pistachio plant poultry farms and cannabis processing companies in wastewater treatment has been studied by a number of researchers (Shoyakubov, Haydarova 1994) [1]. 
The first detrimental impact was encountered by Western countries (England, France, Belgium, the Netherlands, etc.), which followed the path of industrialization and urbanization. This fact has become more evident since the 20th century. Even untouched Anthracite has been reported to contain radioactive dust, DDT pesticides, residues of charred products and more [2].

Of the 19 th century By the second half of the year, sewage treatment in western European cities began. In Russia and Uzbekistan, treatment plants began to be built after the 1950 as a result of the state recovery. L'evovich, the founder of Wastewater Treatment Methods, discovered that the Earth was in 1977, "The Earth is a natural laboratory, and it contains various substances and chemicals and cleanses all kinds of wastes" [3]. Irrigation of lands not only in wastewater but also in agricultural irrigation, its theoretical basis was used in 19th century England, Germany, France. In Russia irrigation of lands in Adessa was applied in Moscow in 1888 in 1898, and in Uzbekistan after 1900. These areas are used for the cultivation of feed crops and cereals, which are prohibited from eating raw fruit and melons and forage crops [4].

The environmental situation in the Republic of Uzbekistan requires the development of not only severe but effective methods for improving the environment and environmental protection. It also demonstrates the importance of using water and aquatic plants in biological treatment of water. Mechanical, physical, chemical, and biological methods are used for sewage treatment. Among these methods, the best use of wastewater treatment methods is for photosynthesis. With the use of the biological treatment method, $80 \%$ of the organic wastewater in the wastewater is treated, with about $40 \%$ physical and chemical and about $30 \%$ mechanical. Under the conditions of the Republic of Uzbekistan within 8-10 months the level of biological purification can be increased up to 90$98 \%$. As a result of many years of research, livestock farms (cattle, poultry and pigs) and industrial (nitrogen-containing waste products) use wastewater from organic matter. The biotechnological method of purification of heavy metals, cyanide, petroleum products and microorganisms has been established and used for the cultivation of various algae and high aquatic plants [5].

The flora of Uzbekistan is diverse, including food, fodder, paints, vitamins, essential oils and medicinal herbs. Recently, plants from other regions have been introduced in Uzbekistan, and their botanical diversity has been enriched. The biological and ecological properties and useful properties are being studied. As a result, the ways in which agriculture, livestock, and medicine are being developed are being developed. For this purpose, not only high plants but also algae and high aquatic plants are introduced and enrich the Republic's gene pool. Pistia (Pistia stratiotes $L$ ) is one of the most widely used herbs in the world $[6,4,1]$.

Biological treatment of wastewater to prevent contamination of organic matter and nitrogen compounds, phenols [7]. Development of methods for the treatment of sustainable wastewater treatment of valuable plant nutrients. Foreign scientific research also shows that activated sludge nanofilting has been developed to improve the quality of industrial and municipal wastewater, with $45 \%$ purification $[8,9]$.

\subsection{The Purpose of the Study}

Wastewater from industrial enterprises and residential areas outlined in my guide for improving biological treatment methods, by means of biological treatment, high aquatic plants have been selected by Pistia stratiotes $L$, Eichornia, and the Carolina Weld resistant assortment. Improvement of technology for biological treatment of domestic wastewater.

\section{METHOD}

Wastewater analyzes and calculations are grown in aquariums in various orgono-mineral nutrient environments at the Knop Mineral Nutrition Research Laboratory. Changes in physicochemical composition of wastewater Yu.Yu.Lure (1975; 1984) [3]. Temperature (in laboratory and biological basins) is determined by mercury thermometer. Nitrates are determined using Solicylate. Nitrites are detected by the Grissa reagent. Nitrogen is determined by ammonium Nesslera reagent. All results obtained by expression are mathematically analyzed on Dospekhov's (1985) personal computer.

\subsection{Science News}

For the first time in the Andizhan region of the Republic of Uzbekistan, it was found that highaltitude algae can be used by the method of biological treatment of municipal wastewater. The wastewater-resistant species is scientifically 
based on research observations. It was found that the wastewater content of such substances as nitrate, nitrite, nitrogen, ammonium, odor, color, alkalinity and acidity, and fats. The scientific basis for improving the treatment technology has been found to be a high-grade algae pistia (Pistia stratiotes L) widely used in biological pools and secondary insulators.

\section{RESULTS AND DISCUSSION}

Selection and recommendation of highly resistant algae species from the assortment tested in the experiments. In the laboratory conditions, the growth dynamics of the azole, eucharia, pistachio algae in liquefied versions of wastewater were monitored for 10-day incremental growth by attracting biomass. According to the results: during the 10 days, the highest growth dynamics in the course of morphological observations wastewater began to turn yellow, with a biomass of $337 \mathrm{~g}$ in $50 \%$ diluted variant. Azolla more wastewater develops better in mineral-rich areas: Eichornia has a high growth biomass of $420 \mathrm{~g}$, $50 \%$ diluted in 10 days, and has grown well with $75 \%$ variation in marine observations, but with $100 \%$ wastewater. development has declined; The Eichornia aquatic plant was not suitable for the biological treatment of wastewater: the pistachio detected a high growth dynamics biomass of $500 \mathrm{~g}$ for 10 days, with $100 \%$ diluted concentrations of high growth rate in morphological observations. Pistia aquatic plants adapted rapidly to the wastewater and began to reproduce.

According to the results of the study, we used biological treatment of high-water plant species such as pistia (Pistia stratiotes), Eichhornia crassipes Solms, azolla (Azolla coroliniana

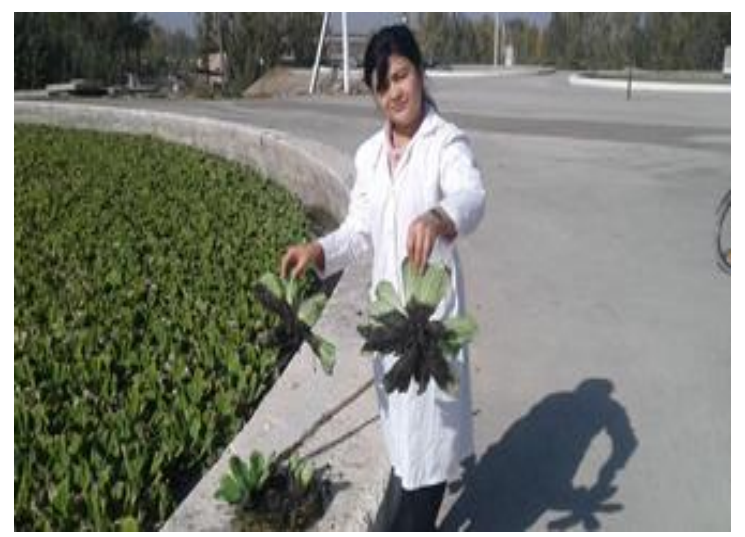

Willd), with the observations of the dynamics of rapid growth and development at high concentrations. We developed a Pistia stratiotes, which is scientifically grounded in improvement, and was recommended for reproduction under laboratory conditions. The physical and chemical properties of wastewater in biological pools and sewers have been determined before planting water (see Table 1.1). Experiments show that BPK5 contains 18-20 mg / I, waste water 52.5$56.5 \mathrm{mg} / \mathrm{I}$, dissolved oxygen $1.5-2.3 \mathrm{mg} / \mathrm{I}$ and dry residue $38.4 .42 .3 \mathrm{mg} / \mathrm{I}$. It was found that the mineral content in wastewater is significantly higher than the permissible norm of nitrate 15.8$16.5 \mathrm{mg} / \mathrm{l}$, nitrite 3.2-3.7 mg / I, nitrogen ammonium 4.3-4.5 mg.

The analysis of waste water sampling at designated areas was found to be more effective in purifying pistia water from biological pools and sewers.

Results of Research Experiments (Table 1.2). Improving the technology of biological treatment of wastewater from pesticide wastewater from Andijan Water Treatment Plant is continued in 2016-2019. This has resulted in a significant reduction in the level of orgono-mineral pollution in the open water basin Black Sea.

Comparing scientific research with other research works: scientists Shoyakubov R.Sh; Buriyev S.B; Khaitov has developed biotechnology for cleaning wastewater from algae, eichornia, azolla, ricaska, chlorella green algae in the area of spinning plants, hydrolysis plants, poultry and cattle breeding plants. [10,11]. Wide application of biodegradable waterresistant plants with biological treatment in aquatic nutrient environments.

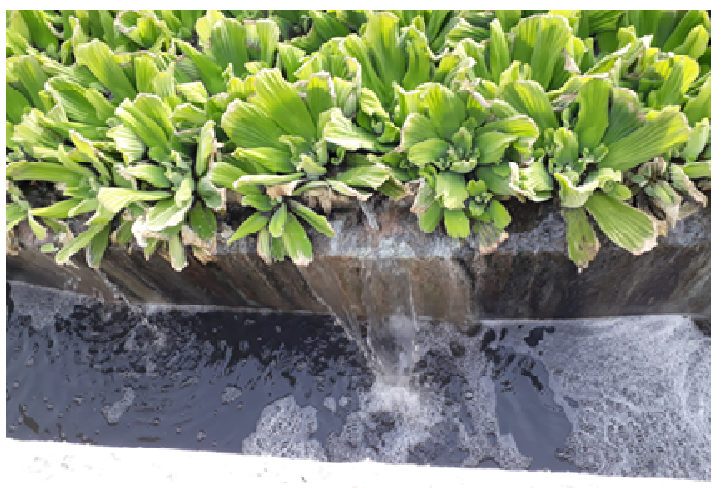

Photo-1. High Pistia (Pistia stratiotes) 
Kuchkarova et al.; ARRB, 33(5): 1-5, 2019; Article no.ARRB. 52487

Table. 1.1 Water treatment plant in Andijan physical and chemical composition of wastewater in biological pools and sewers before planting

\begin{tabular}{|c|c|c|c|c|c|c|c|c|c|c|}
\hline \multirow[t]{2}{*}{ Experience types } & \multicolumn{10}{|c|}{ Indicators } \\
\hline & $\mathrm{pH}$ & color & smell & Nitrate $\mathbf{M g \backslash I}$ & $\begin{array}{l}\text { Nitrite } \\
\text { Mg / I }\end{array}$ & $\begin{array}{l}\text { Ammonium } \\
\text { Mgll }\end{array}$ & $\begin{array}{l}\text { BPK5 } \\
\mathrm{Mg} / \mathrm{I}\end{array}$ & $\begin{array}{l}\text { XPK } \\
\text { Mgll }\end{array}$ & $\begin{array}{l}\text { Dry residue } \\
\text { Mg\ I }\end{array}$ & $\begin{array}{l}\text { Oxygen } \\
\mathrm{Mg} / \mathrm{I}\end{array}$ \\
\hline $\begin{array}{l}\text { Biological from pools } \\
\text { waste water }\end{array}$ & 7,5 & Brown & 5,0 & 16,5 & 3,2 & 4,3 & 18 & 52,5 & 38,4 & 2,3 \\
\hline $\begin{array}{l}\text { First from the silencer } \\
\text { coming out sewage }\end{array}$ & 7,5 & Brown & 5,0 & 15,8 & 3,7 & 4,5 & 20 & 56,5 & 42,3 & 1,5 \\
\hline $\begin{array}{l}\text { Second from the silencer } \\
\text { waste water }\end{array}$ & 7,5 & Brown & 5,0 & 15,8 & 3,7 & 4,5 & 20 & 56,5 & 42,3 & 1,5 \\
\hline $\begin{array}{l}\text { Third coming out of the } \\
\text { muffler sewage }\end{array}$ & 7,5 & Brown & 5,0 & 15,8 & 3,7 & 4,5 & 20 & 56,5 & 42,3 & 1,5 \\
\hline
\end{tabular}

Table. 1.2 Water treatment plant in Andijan city physiochemical composition of wastewater in biological pools and seals after planting (1 month)

\begin{tabular}{|c|c|c|c|c|c|c|c|c|c|c|}
\hline \multirow[t]{2}{*}{ Experience types } & \multicolumn{10}{|c|}{ Indicators } \\
\hline & pH & color & smell & $\begin{array}{l}\text { Nitrate } \\
\text { Mg\ I }\end{array}$ & $\begin{array}{l}\text { Nitrite } \\
\mathrm{Mg} / \mathrm{I}\end{array}$ & $\begin{array}{l}\text { Ammonium } \\
\text { Mgll }\end{array}$ & $\begin{array}{l}\text { BPK5 } \\
\mathrm{Mg} / \mathrm{I}\end{array}$ & $\begin{array}{l}\text { XPK } \\
\text { MglI }\end{array}$ & $\begin{array}{l}\text { Dry residue } \\
\text { Mg\ I }\end{array}$ & $\begin{array}{l}\text { Oxygen } \\
\mathrm{Mg} / \mathrm{I}\end{array}$ \\
\hline $\begin{array}{l}\text { Biological from pools } \\
\text { waste water }\end{array}$ & 7,5 & colorless & High & - & - & - & 8,5 & 29,5 & 22,8 & 8,5 \\
\hline $\begin{array}{l}\text { First from the silencer } \\
\text { coming outsewage }\end{array}$ & 7,5 & colorless & High & - & - & - & 9,2 & 32,3 & 25,2 & 6,5 \\
\hline $\begin{array}{l}\text { Second from the silencer } \\
\text { waste water }\end{array}$ & 7,5 & colorless & High & - & - & - & 9,2 & 32,3 & 25,2 & 6,5 \\
\hline Third coming out of the muffler sewage & 7,5 & colorless & High & - & - & - & 9,2 & 32,3 & 25,2 & 6,5 \\
\hline
\end{tabular}


According to him, the composition of water between communal domestic wastewater and live and poultry wastewater differs significantly. The dynamics of growth of pistachio seedlings planted in biological pools and sewers to improve biological purification technology at the facility of our research was $85-90 \%$.

\section{CONCLUSION}

The ecology of pistachio aquifers serves as a basis for improving biological wastewater treatment technology.

\section{COMPETING INTERESTS}

Authors have declared that no competing interests exist.

\section{REFERENCES}

1. Articles published. Eishman GI, Litfak AA. Water supply and wastewater treatment of chemical fiber enterprises. 1971;154.

2. Book. Publishers. Zhdanov AD, Cirilng D. Aquarium and aquatic plants.St.
Pemterburg, Gidromemoizdat. 1991;186188.

3. Method. L'evovich $A$; Treatment of sewage.1977;19-22.

4. Dissertations. Shoyakubov RSh. Biology of pististeleorisoid and the possibility of its practical use: Tashkent. 1993;46.

5. Book: Publishers. Gillet. Watanabe. I. Microbiology of tropical soils and the rand of productivity / the hague: Nijhoff / Junk. 1982;169-185.

6. Monographs. Muzaffrov MA. Flora of algae ponds of Central Asia. Tashkent. Science. 1965;117.

7. Articles. Eiroa M @.ELSEVIER. Science Direct. 2008;103-114.

8. Articles. Pell M, Worman A. @.ELSEVIER. Science Direct. 2008;46-58.

9. Articles. Sahin E. @.ELSEVIER. Science Direct. 2010;117-126.

10. Method. Yu.Yu.Lure; Changes in the physico- chemical composition of wastewater. 1984;7-16.

11. Article. Shoyakubov R. Sh, Khalmuradov AG, Kutliev D. Recombinant po Effective biotechnology pisti telorezovid. Tashkent.1993;30.

(c) 2019 Kuchkarova et al.; This is an Open Access article distributed under the terms of the Creative Commons Attribution License (http://creativecommons.org/licenses/by/4.0), which permits unrestricted use, distribution, and reproduction in any medium, provided the original work is properly cited.

Peer-review history:

The peer review history for this paper can be accessed here: https://sdiarticle4.com/review-history/52487 